\title{
Poejo (Cunila galioides Benth.) Production in Five Agroecological Regions of Rio Grande do Sul
}

\author{
Gabriel Fernandes Pauletti ${ }^{1,2}$ \\ https://orcid.org/0000-0001-9850-3682 \\ Wendel Paulo Silvestre ${ }^{1^{*}}$ \\ https://orcid.org/ 0000-0002-9376-6405 \\ Luciana Duarte Rota ${ }^{1}$ \\ https://orcid.org/0000-0002-8218-9366
}

Sergio Echeverrigaray ${ }^{1}$

https://orcid.org/ 0000-0002-9111-0701

Ingrid Bergman Inchausti de Barros²
http://orcid.org/0000-0003-1040-5303

\begin{abstract}
${ }^{1}$ University of Caxias do Sul; Postgraduate Program in Biotechnology, Rio Grande do Sul, Brazil; ${ }^{2}$ Federal University of Rio Grande do Sul, Postgraduate Program in Plant Science, Rio Grande do Sul, Brazil.

Received: 2019.08.08; Accepted: 2020.03.21.
\end{abstract}

${ }^{*}$ Correspondence: wpsilvestrel@ucs.br; Tel.: +55-54-32182965 (W.P.S.)

\section{HIGHLIGHTS}

- Nine populations of poejo were cultivated in five different regions of RS state.

- It was observed a genotype vs. environment interaction.

- Santa Lúcia (SL) population presented the greatest environmental stability.

- André da Rocha (AR) population presented the highest essential oil production.

Abstract: The objective of this study was to evaluate the biomass and essential oil production of nine populations of poejo (Cunila galioides) cultivated in five agroecological regions of the state of Rio Grande do Sul, under different edaphoclimatic conditions. The experiments were performed in field conditions in Erechim, Caxias do Sul, Pelotas, São Francisco de Paula, and Santa Vitoria do Palmar. The experimental design was completely randomized, with nine populations, eight plants per plot and four repetitions. The following were evaluated: biomass production and essential oil chemical composition and yield. The data underwent ANOVA, followed by Tukey's multiple range test. The adaptability and stability of the populations in the different environments were also evaluated by regression analysis. The results showed great differences between the populations and cultivation sites, with genotype vs. environment interaction. Most populations presented the best biomass production results at Erechim. Pelotas and Santa Vitória do Palmar were the worst locations for poejo production, mainly due to a water deficit occurred during the experiment. The Santa Lucia population presented broad stability and the greatest adaptability to the environments for biomass and essential oil production, but its average production was not satisfactory. The André da Rocha population presented the highest average production of essential oil, and was favored in favorable environments. Regarding essential oil chemical composition, the populations kept stable contents of the major compounds at all locations, with a few variations. In some populations, a higher concentration of sesquiterpenes was observed, which can be attributed to environmental stress.

Keywords: essential oil; chemotype; environmental influence; genotype vs. environment interaction. 


\section{INTRODUCTION}

Poejo (Cunila galioides Benth. - Lamiaceae) is an aromatic and medicinal plant from South Brazil, being found in high-altitude regions. It is commonly found in the 'Campos de Cima da Serra', in the northern upper slope of Rio Grande do Sul, and in the Plateaus of Santa Catarina and Rio Grande do Sul states [1-3]. This species presents the chemotypes citral, ocimene and menthene, according to the major compounds present in the essential oil, which are partially related to the geographical distribution of the populations [4]. The chemical composition of the essential oil of several plant species is mainly attributed to a genetic regulation, with little influence from environmental factors [5].

Although $C$. gallioides is a species with most of its potential still unexplored, there are studies using poejo essential oil as an anesthetic on Rhamdia quelen, with positive results [6], beyond the already reported use in cosmetics industry [7].

Echeverrigaray and coauthors [4], cultivating poejo clones in a distinct environment from their natural habitat, observed that the essential oil of these populations presented the same composition of the wild plants. On the other hand, Loziene and Venskutonis [8], cultivating Thymus puleigoides in the same place for five consecutive years, observed that some chemotypes may suffer great environmental effects, modifying considerably the content of the major compounds of the essential oil relative to the content found in wild plants; generally the composition return to the original contents, according to the climatic conditions in each year of cultivation.

A classic example of the environmental effect on essential oil composition and quality is the effect on peppermint (Mentha $\times$ piperita - Lamiaceae), which, according to Shahi and coauthors [9], has the monoterpene metabolism strongly affected by the environment. For this species, smaller photoperiod and higher temperatures promote a decrease of menthol content and an increase in menthofuran content, reducing the quality of the essential oil [10].

Prior to the cultivation of aromatic and medicinal species, it must be taken into account that, due to the soil type and climate on which these species develop, they can present a distinct behavior not only in production aspect, but also in the chemical composition of the transformed product (essential oil), which will determine the quality of the final product [11-13].

One of the stages involved in the process of domestication of native aromatic and medicinal plants is the production of the plants in some cultivation system, generally distinct from its original habitat, which may cause qualitative and quantitative modifications in the chemical properties of the essential oil and extracts. Therefore, this work aimed to evaluate the biomass and essential oil production of nine poejo plant populations under different climatic and edaphological cultivation environments.

\section{MATERIAL AND METHODS}

Nine populations of poejo from different municipalities of Rio Grande do Sul and Santa Catarina states, South Brazil, were studied (Table 1). The populations were collected between 1999 and 2001 [14] and were kept in vitro and in vivo in the Laboratory of Plant Biotechnology and in the experimental field of the Biotechnology Institute of the University of Caxias do Sul as part of the germplasm bank of native aromatic and medicinal species of the Laboratory of Essential Oils of the university. The exsiccates were deposited in the herbarium (HUCS) of the university.

Table 1. Place of collection and chemotype of the nine poejo (C. galioides) populations studied in the present work.

\begin{tabular}{ccc}
\hline Population & Place of collection & Chemotype $(\mathrm{CT})^{1}$ \\
AR & André da Rocha - RS & citral \\
citral \\
CA & Muitos Capões - RS & ocimene \\
BJ & Capão Alto - RS & ocimene \\
CAM & Bom Jardim da Serra - RS & ocimene \\
LA & Cambará do Sul - RS & menthene \\
SJ & Lages - SC & menthene \\
SL & São Joaquim - SC & menthene \\
SJ & Santa Lúcia do Piaí ${ }^{2}-\mathrm{RS}$ & menthene \\
\hline
\end{tabular}

1 - according to Echeverrigaray and coauthors. [4]; ${ }^{2}$ - district of the city of Caxias do Sul, RS.

The clones were made by cutting from matrix plants cultivated in a greenhouse. The cutting was performed by applying IBA at $250 \mathrm{mg} / \mathrm{L}$ in the base of the cutting, using polystyrene trays with 72 cells, with carbonized rice husk as substrate, kept under intermittent nebulization for 60 days. 
The experiment was carried out in field conditions at the municipalities of Erechim, São Francisco de Paula, Caxias do Sul, Pelotas, and Santa Vitória do Palmar, corresponding to the agroclimatic conditions of Planalto Médio, Serra do Nordeste, Planalto Superior, Grandes Lagoas, and Litoral, respectively [15]. Table 2 presents the geographical localization and some edaphoclimatic characteristics of each place of cultivation.

Table 2. Geographical localization and edaphoclimatic characteristics of each place where the nine population of poejo (C. galioides) were cultivated.

\begin{tabular}{|c|c|c|c|c|c|c|}
\hline Place & $\begin{array}{l}\text { Geog. } \\
\text { Coord. }\end{array}$ & $\begin{array}{c}A \\
(m)\end{array}$ & $\begin{array}{c}\mathrm{R}^{*} \\
(\mathrm{~mm})\end{array}$ & $\begin{array}{c}\mathrm{T}^{*} \\
\left({ }^{\circ} \mathrm{C}\right)\end{array}$ & $\begin{array}{l}\mathrm{RH}^{*} \\
(\%)\end{array}$ & Soil classification \\
\hline Erechim & $\begin{array}{l}27^{\circ} 38^{\prime} \mathrm{S} \\
52^{\circ} 16^{\prime} \mathrm{W}\end{array}$ & 631 & 1700 & 18 & 77.5 & typical red latosol aluminoferric \\
\hline Caxias do Sul & $\begin{array}{l}29^{\circ} 09^{\prime} \mathrm{S} \\
51^{\circ} 10^{\prime} \mathrm{W}\end{array}$ & 725 & 1600 & 16 & 80.0 & aluminic humic cambisol \\
\hline $\begin{array}{c}\text { São Francisco de } \\
\text { Paula }\end{array}$ & $\begin{array}{l}28^{\circ} 26^{\prime} \mathrm{S} \\
50^{\circ} 35^{\prime} \mathrm{W}\end{array}$ & 930 & 2200 & 15 & 80.0 & aluminic humic cambisol \\
\hline Pelotas & $\begin{array}{l}31^{\circ} 41^{\prime} \mathrm{S} \\
52^{\circ} 25^{\prime} \mathrm{W}\end{array}$ & 54 & 1800 & 17 & 80.0 & dystrophic red-yellow acrisol \\
\hline $\begin{array}{c}\text { Santa Vitória do } \\
\text { Palmar }\end{array}$ & $\begin{array}{l}33^{\circ} 31^{\prime} \mathrm{S} \\
53^{\circ} 22^{\prime} \mathrm{W}\end{array}$ & 8 & 1200 & 17 & 80.0 & eutrophic hydromorphic planosol \\
\hline
\end{tabular}

A - altitude; R - rainfall; T - temperature; RH - relative humidity; ${ }^{*}$ annual means.

The soil of each experimental plot was analyzed prior to the installment of the experiment; the soil fertility parameters were determined according to Tedesco and coauthors [16], and the results are presented in Table 4. The climatic, rainfall and temperature data were collected by meteorological stations in the referred places, with exception of São Francisco de Paula, where it was not possible to obtain the climatic data.

The experimental design was completely randomized, with 9 populations, 8 plants for each plot, and four repetitions, totaling 288 plants in each place. Based on previous experiments, the used spacing was $0.6 \mathrm{~m}$ between lines and $0.5 \mathrm{~m}$ between plants in the line in an area of $97.5 \mathrm{~m}^{2}(15.0 \mathrm{~m} \times 6.5 \mathrm{~m})$. The area was prepared by plowing and harrowing, and a base fertilization of $500 \mathrm{~kg} / \mathrm{ha}$ of NPK 5:20:10 was carried out. The fertilizer was applied by throwing before the planting and incorporated in the soil by the last harrowing.

The planting was carried out between December 8 and 22, 2003 (Table 3); a sprinkling irrigation was carried out after the plantation in all places, with exception of São Francisco de Paula, because a high rainfall occurred in this place right after the planting. Two to three manual weedings were carried out, depending on the necessity, during the experiment.

Table 3. Planting and harvesting dates and cultivation period of the nine poejo (C. galioides) populations in each place.

\begin{tabular}{|c|c|c|c|}
\hline \multirow{2}{*}{ Place } & \multicolumn{2}{|c|}{ Date } & \multirow{2}{*}{$\begin{array}{l}\text { Cultivation time } \\
\text { (days) }\end{array}$} \\
\hline & Planting & Harvesting & \\
\hline Erechim & $08 / 12 / 2003$ & $22 / 03 / 2004$ & 106 \\
\hline Caxias do Sul & 22/12/2003 & $01 / 04 / 2004$ & 102 \\
\hline São Francisco de Paula & $13 / 12 / 2003$ & $19 / 03 / 2004$ & 98 \\
\hline Pelotas & $19 / 12 / 2003$ & 29/03/2004 & 102 \\
\hline Santa Vitória do Palmar & $18 / 12 / 2003$ & $29 / 03 / 2004$ & 101 \\
\hline
\end{tabular}

The harvesting was carried out between March 19 and April $1^{\text {st }}$, 2004, when the plants were at full bloom. The experimental plots were collected and the plant samples were dried in a drier with forced air circulation at $35^{\circ} \mathrm{C}$ until constant mass; the aerial dry matter - ADM (g/plant) and biomass yield $(\mathrm{kg} / \mathrm{ha}$ ) were determined, considering a plant density of 33,200 plants/ha. $100 \mathrm{~g}$ of a homogeneous sample of each population and each place underwent essential oil extraction by hydrodistillation for $1 \mathrm{~h}$. The essential oil yield was calculated by the following equation.

$$
Y_{E O}=\frac{100 \times V_{E O}}{m_{p}}
$$

Where $\mathrm{Y}_{\mathrm{EO}}$ corresponds to essential oil yield $(\% \mathrm{v} / \mathrm{m}), \mathrm{V}_{\mathrm{EO}}$ is the collected volume of essential oil at the end of the extraction, and $m_{p}$ is the plant mass used in the extraction.

The data underwent analysis of variance (ANOVA) and the means were compared by Tukey's multiple range test at $5 \%$ probability; the following parameters were evaluated: biomass yield $(\mathrm{kg} / \mathrm{ha})$ and essential oil yield (L/ha). With these parameters the stability and adaptability of each population were calculated using 
the method proposed by Eberhart and Russel [17] by using GENES software [18]. This methodology is based in a linear regression equation with the following statistical model:

$$
Y_{i j}=m+\beta_{i} I_{i}+\delta_{i j}+\varepsilon_{i j}
$$

Where 'Yij' corresponds to the mean of the genotype 'i' in the environment ' $j$ '; ' $m$ ' is the mean of the genotype ' $i$ ' in all environments; ' $B i$ ' corresponds to the linear regression coefficient that measures the response of the ' $i$ '-th genotype to environmental variation; $I$ is the environmental index; ' $\delta i j$ ' corresponds to the regression deviation, and ' $\varepsilon i$ ' is the average experimental error.

In the city of Erechim was carried out a productivity evaluation of the nine poejo populations in the second year of cultivation. The harvesting was carried out in April, 2005. The biomass yield $(\mathrm{kg} / \mathrm{ha})$ and essential oil yield (L/ha) were evaluated, the results were compared with the first year of cultivation by ANOVA and the means were compared by Tukey's multiple range test at $5 \%$ probability. The essential oils chemical composition was determined by GC/MS and GC-FID, using the essential oil from the poejo plants cultivated between 2003 and 2004.

GC/MS analysis was performed on a Hewlett Packard (HP) model 6890 Gas Chromatograph, coupled to a HP 6890/MSD5973 mass selective detector, equipped with a HP Chemstation software and a Wiley 275 spectral library. A HP-5MS fused silica capillary column $(30 \mathrm{~m} \times 250 \mu \mathrm{m})$ with $0.50 \mu \mathrm{m}$ film thickness (HP, Palo Alto, CA, USA) was used. The column temperature was $60^{\circ} \mathrm{C}$ for $8 \mathrm{~min}$, then raised to $180{ }^{\circ} \mathrm{C}$ at $3^{\circ} \mathrm{C} / \mathrm{min}$ and finally to $230^{\circ} \mathrm{C}$ at $20^{\circ} \mathrm{C} / \mathrm{min}$. The injector temperature was $220^{\circ} \mathrm{C}$ and interface temperature was $250^{\circ} \mathrm{C}$. The split ratio was $1: 100$, the carrier gas was helium at $56 \mathrm{kPa}$, with a flow rate of $1.0 \mathrm{~mL} / \mathrm{min}$, and the ionization energy was $70 \mathrm{eV}$. The LRI (linear retention index) of the compounds was calculated in accordance with Adams [19]; the literature LRI values were also obtained from Adams [19].

Quantitative analysis was carried out using a HP 6890 model Gas Chromatograph, coupled to a FID detector and a HP Chemstation software. A HP-5MS fused silica capillary column (30 m x $250 \mu \mathrm{m})$ with 0.50 $\mu \mathrm{m}$ film thickness (HP) was used with the same temperature program as the GC-MS; FID temperature of $220^{\circ} \mathrm{C}$; split ratio of $1: 100$, hydrogen as carrier gas at $34 \mathrm{kPa}$ and a flow rate of $1.0 \mathrm{~mL} / \mathrm{min}$, and an injected volume of $1 \mu \mathrm{L}$. The quantification used 1-octanol as the internal standard, injection of $25 \mu \mathrm{L}$ of a 1 -octanol solution of $30.22 \mathrm{~g} / \mathrm{L}$ in hexane $(755 \mu \mathrm{g}$ of 1 -octanol injected in each analysis).

\section{RESULTS AND DISCUSSION}

\section{Edaphoclimatic conditions in each cultivation place}

The rainfall and temperature records of each place, as well as the soil fertility analyses, presented differences. The distinct characteristics of climate and soil, some of them expected and characteristic of each region, and other disclosing specific data of the agricultural year relative to this work, are presented hereafter. The relevant discussions are presented with the productivity data.

The state of Rio Grande do Sul has, according to the Köppen classification, the climatic types Cfa and $\mathrm{Cfb}$, located in the subtropical climate, with rainfall reasonably well distributed throughout the year. The Cfa type is dominant and indicates hot summers; the Cfb type occurs in the region with higher altitude (Campos de Cima da Serra and Serra do Nordeste), with milder summers [20].

The annual average rainfall in Rio Grande do Sul state is approximately $1590 \mathrm{~mm}$; in the northern half, the annual average rainfall is higher than the state mean, being smaller in the southern half. The average rainfall in the summer period (December 2003 to March 2004) was approximately $570 \mathrm{~mm}$; variations occurred as a result of climatic phenomena such as the El Niño and La Niña [20,21].

The accumulated rainfall during the experiment, from December 2003 to April 2004, varied among places. The higher amounts of rain occurred at Caxias do Sul $(729.5 \mathrm{~mm})$ and Erechim $(681.4 \mathrm{~mm})$; the smallest amounts occurred at Santa Vitória do Palmar $(448.7 \mathrm{~mm})$ and Pelotas $(404.4 \mathrm{~mm})$. The rainfall was below the state average $(570 \mathrm{~mm})$ in the southern half of the state, and above average in the northern half, but poorly distributed (Figure 1). 



Figure 1. Monthly rainfall occurred in the five places were the poejo ( $C$. galioides) populations were cultivated. Data from São Francisco de Paula was not available.

The monthly average temperatures during the experiment were distinct in each place, mostly in the places with higher altitude (Figure 2). At Caxias do Sul it was observed the lowest monthly average temperature for the period $\left(19.7^{\circ} \mathrm{C}\right)$, followed by Erechim $\left(21.3^{\circ} \mathrm{C}\right)$.

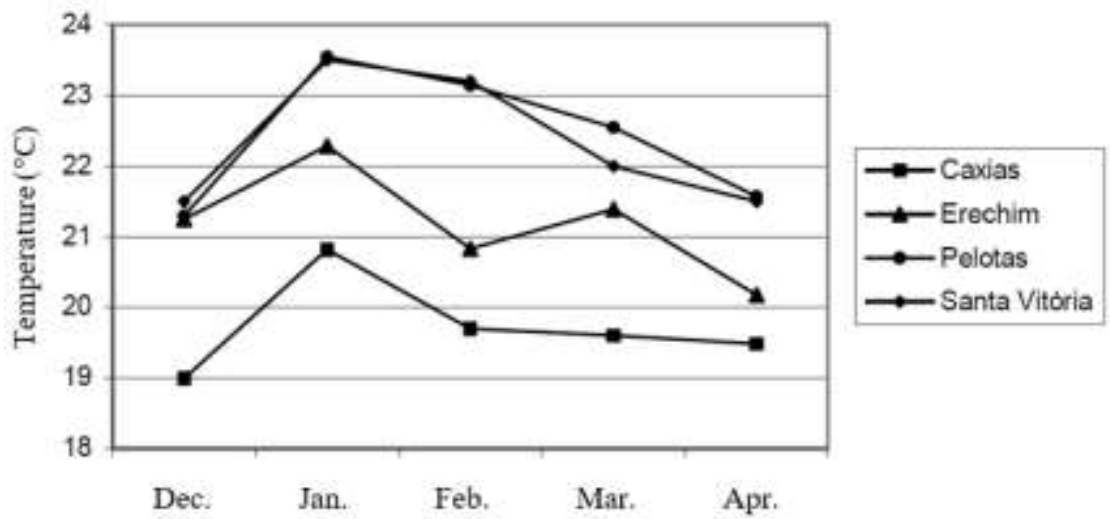

Figure 2. Average monthly temperature in four places where poejo (C. galioides) populations were cultivated. Data from São Francisco de Paula was not available.

Pelotas and Santa Vitória do Palmar presented the highest temperatures, with small variations between these two cities. Their average temperatures were 22.5 and $22.3^{\circ} \mathrm{C}$, respectively. The highest averages were recorded in January for all places (Figure 2).

Despite being not possible to obtain the records of specific climatic data of São Francisco de Paula, it can be considered, due to the proximity and region characteristics, that rainfall and average temperatures were similar to the ones of Caxias do Sul.

Regarding soil fertility, the main differences were in the clay, P, K, Zn, Cu, and Mn contents (Table 4). 
Table 4. Soil fertility analysis of each cultivation place.

\begin{tabular}{ccccccc}
\hline Parameter & Unit & Erechim & $\begin{array}{c}\text { Caxias do } \\
\text { Sul }\end{array}$ & $\begin{array}{c}\text { São F. de } \\
\text { Paula }\end{array}$ & $\begin{array}{c}\text { Pelotas } \\
\text { Santa V. do } \\
\text { Palmar }\end{array}$ \\
\hline Clay & $\% \mathrm{~m} / \mathrm{v}$ & $>56$ & 27 & 11 & 16 & 14 \\
$\mathrm{pH}$ & - & 5.6 & 5.8 & 5.9 & 5.8 & 5.9 \\
$\mathrm{pH}-\mathrm{SMP}$ & - & 6.0 & 6.5 & 5.6 & 6.8 & 6.2 \\
$\mathrm{P}$ & $\mathrm{mg} / \mathrm{L}$ & 4.0 & 28.0 & 6.6 & 15.0 & 7.7 \\
$\mathrm{~K}$ & $\mathrm{mg} / \mathrm{L}$ & 255 & 198 & 81 & 139 & 141 \\
$\mathrm{OM}$ & $\% \mathrm{~m} / \mathrm{v}$ & 3.3 & 3.4 & 5.3 & 2.4 & 3.0 \\
$\mathrm{Al} 1$ & $\mathrm{cmol} / \mathrm{L}$ & 0.0 & 0.0 & 0.0 & 0.0 & 0.0 \\
$\mathrm{Ca} 1$ & $\mathrm{cmol} / \mathrm{L}$ & 8.4 & 7.4 & 12.6 & 4.0 & 4.3 \\
$\mathrm{Mg} 1$ & $\mathrm{cmol} / \mathrm{L}$ & 4.4 & 3.7 & 6.9 & 2.1 & 1.6 \\
$\mathrm{~S}$ & $\mathrm{mg} / \mathrm{L}$ & 15.0 & 6.1 & 15.0 & 7.5 & 8.8 \\
$\mathrm{Zn}$ & $\mathrm{mg} / \mathrm{L}$ & 3.0 & 13.0 & 0.5 & 1.8 & 5.4 \\
$\mathrm{Cu}$ & $\mathrm{mg} / \mathrm{L}$ & 5.9 & 10.6 & 0.1 & 0.7 & 3.3 \\
$\mathrm{~B}$ & $\mathrm{mg} / \mathrm{L}$ & 0.9 & 0.8 & 1.1 & 1.0 & 0.9 \\
$\mathrm{Mn}$ & $\mathrm{mg} / \mathrm{L}$ & 52 & 10 & 2 & 5 & 59 \\
$\mathrm{H}+\mathrm{Al}$ & $\mathrm{cmol} / \mathrm{L}$ & 3.6 & 2.5 & 5.1 & 1.7 & 3.0 \\
$\mathrm{CEC}$ & $\mathrm{cmol} / \mathrm{L}$ & 17.1 & 14.1 & 24.8 & 8.2 & 9.3 \\
$\mathrm{Base} \mathrm{sat.}$ & $\%$ & 79 & 82 & 79 & 79 & 67 \\
$\mathrm{Al} \mathrm{sat.}$ & $\%$ & 0 & 0 & 0 & 0 & 0 \\
$\mathrm{Ca} / \mathrm{Mg}$ & - & 1.9 & 2.0 & 1.8 & 1.9 & 1.7 \\
$\mathrm{C} / \mathrm{K}$ & - & 13.0 & 15.0 & 61.0 & 11.0 & 12.0 \\
$\mathrm{Mg} / \mathrm{K}$ & - & 7.0 & 7.0 & 33.0 & 6.0 & 4.4 \\
\hline
\end{tabular}

1 - exchangeable contents.

Soil acidity, considering $\mathrm{pH}$ in water, was classified as mildly acidic in all places. For organic matter (OM), only São Francisco de Paula presented a high content (>5.0\%); Pelotas presented a low content $(<2.5 \%)$, and the other places presented moderate (between 2.5 and $5.0 \%$ ) contents [15].

The cation exchange capacity (CEC) was high at Erechim and São Francisco de Paula and moderate in the other places. The percentage of base saturation was average only at Santa Vitória do Palmar, being considered as high at Caxias do Sul and considered as adequate in the other places [22].

All soils presented high $\mathrm{K}$ contents, with exception of São Francisco de Paula, whose $\mathrm{K}$ content was considered as sufficient. P contents were high at Caxias do Sul, moderate at Pelotas, and low in the other places. Ca contents ranged between medium and high and Mg contents presented themselves high in all places [23].

The $\mathrm{Ca} / \mathrm{Mg}$ and $\mathrm{Mg} / \mathrm{K}$ molar relations were in imbalance ranges. The $\mathrm{Ca} / \mathrm{K}$ molar relation was in balance range only at Erechim and Caxias do Sul, at the other places it was in imbalance ranges (Table 4). According to Rheinheimer and coauthors [15], the interpretation of these relations among exchangeable cations must be considered with caution because there is no clear crop response to the adjustment of these relations when the absolute contents of the nutrients are above the sufficiency levels.

$\mathrm{Cu}$ and $\mathrm{Mn}$ contents were sufficient in nearly all locations. Only the Cu content at São Francisco de Paula was considered as a low level [23]. It is worth mentioning the high $\mathrm{Cu}$ and $\mathrm{Zn}$ contents at Caxias do Sul and Mn contents at Erechim and Santa Vitória do Palmar. The high Cu content at Caxias do Sul may be attributed to the fact that the experimental area was near to the former Viticulture Experimental Station of the state, where the use of copper-based fungicides was common. Regarding Mn, clayey or poorly drained soils, commonly found at Erechim and Santa Vitória do Palmar, respectively, may contain higher contents of this element in the free form $\left(\mathrm{Mn}^{+2}\right)$ [22].

\section{Biomass and essential oil production}

Table 5 presents the average yield values for biomass production for the nine poejo populations and the cultivation places. It was observed statistical differences among populations and places and the presence of significant interactions between these two factors. 
Table 5. Estimated yield of dry biomass ( $\mathrm{kg} / \mathrm{ha}$ ) of the nine poejo (C. galioides) populations cultivated in five regions of Rio Grande do Sul.

\begin{tabular}{|c|c|c|c|c|c|c|c|}
\hline \multirow[b]{2}{*}{ POP } & \multirow[b]{2}{*}{ CT } & \multicolumn{5}{|c|}{ Place } & \multirow[b]{2}{*}{$\begin{array}{l}\text { Mean } \\
\text { (POP) }\end{array}$} \\
\hline & & Erechim & $\begin{array}{c}\text { Caxias do } \\
\text { Sul }\end{array}$ & $\begin{array}{l}\text { S. F. de } \\
\text { Paula }\end{array}$ & Pelotas & $\begin{array}{l}\text { S. V. do } \\
\text { Palmar }\end{array}$ & \\
\hline AR & citral & $781.1 \mathrm{~b} \mathrm{~A}$ & 520.5 a B & 255.9 a C & 149.6 a C & 123.3 a C & $366.1 \mathrm{a}$ \\
\hline SL & menthene & 546.9 c A & 294.5 bc B & 232.1 a BC & 99.1 a C & 112.3 a C & $257.0 \mathrm{~b}$ \\
\hline BJ & ocimene & $325.7 \mathrm{~d} A$ & $172.0 \mathrm{bc} \mathrm{B}$ & 180.1 a B & 70.8 a B & 45.6 a B & $158.8 \mathrm{c}$ \\
\hline LA & menthene & 498.2 c A & 196.6 bc B & 185.9 a B & 110.0 a B & 63.7 a B & $210.9 \mathrm{bc}$ \\
\hline CAM & ocimene & 148.8 e BC & 331.7 b A & 255.0 a $A B$ & 94.9 a C & 91.0 a C & $184.3 \mathrm{bc}$ \\
\hline CA & ocimene & 978.6 a A & 513.4 a B & 288.6 a C & 159.0 a CD & 76.8 a D & $403.3 \mathrm{a}$ \\
\hline SJ & menthene & 538.9 c A & $151.0 \mathrm{c} \mathrm{B}$ & 178.7 a B & 130.0 a B & 75.0 a B & $214.7 b c$ \\
\hline $\mathrm{MC}$ & citral & 954.6 c A & 579.1 a B & 200.8 a C & 138.3 a C & $144.1 \mathrm{a} C$ & $402.8 \mathrm{a}$ \\
\hline SJ2 & menthene & 547.4 c A & 198.4 bc BC & 220.8 a B & 104.2 a BC & 62.5 a C & $226.7 \mathrm{bc}$ \\
\hline \multicolumn{2}{|c|}{ Mean (place) } & $591.1 \mathrm{~A}$ & $328.6 \mathrm{~B}$ & $222.0 \mathrm{C}$ & $117.35 \mathrm{D}$ & $87.9 \mathrm{D}$ & 269.43 \\
\hline
\end{tabular}

Means followed by the same letter, uppercase in row and lowercase in column, do not differ between themselves by Tukey's range test at 5\%. AR - André da Rocha; SL - Santa Lúcia; BJ - Bom Jardim; LA - Lages; CAM - Cambará do Sul; CA - Capão Alto; SJ - São Joaquim; MC - Muitos Capões; LV - Lagoa Vermelha.

In Erechim, the highest yields were observed for the Capão Alto (CA - CT ocimene) and Muitos Capões (MC - CT citral) populations, with 978.6 and $954.6 \mathrm{~kg} / \mathrm{ha}$, respectively, being superior to the other populations and not differing statistically between themselves. The André da Rocha (AR) population (CT citral) yielded $781.1 \mathrm{~kg} / \mathrm{ha}$, being inferior to the Capão Alto and Muitos Capões populations, and superior to the others. The populations Lages (LA), São Joaquim (SJ), Santa Lúcia (SL), and São Joaquim 2 (SJ2 - all CT menthene) yielded intermediate values, ranging from 498.2 to $547.4 \mathrm{~kg} / \mathrm{ha}$, being superior to the Bom Jardim da Serra and Cambará do Sul populations, both of ocimene chemotype.

In Caxias do Sul, the behavior was partially distinct, because, besides the Capão Alto (513.4 kg/ha) and Muitos Capões (579.1 kg/ha) populations, the André da Rocha population ( $520.5 \mathrm{~kg} / \mathrm{ha}$ ) was also one of the most productive. In the other places there were no important statistical differences for biomass yield among the populations.

Between places, the plants cultivated at Erechim presented the highest biomass yields, for all populations, with exception of the Cambará do Sul (CAM) population. This population presented better performances at Caxias do Sul and São Francisco de Paula, with yields of 331.7 and $225.0 \mathrm{~kg} / \mathrm{ha}$, respectively. The Bom Jardim da Serra (BJ), Lages (LA), and São Joaquim (SJ) populations have not presented statistical difference among Caxias do Sul, São Francisco de Paula, Pelotas, and Santa Vitória do Palmar.

The André da Rocha (AR), Capão Alto (CA), and Muitos Capões (MC) populations cultivated at Caxias do Sul presented higher biomass yields than at São Francisco de Paula, Pelotas, and Santa Vitória do Palmar.

The Santa Lúcia (SL) population presented the same behavior at Caxias do Sul and São Francisco de Paula, presenting the smaller yields when cultivated at Pelotas and Santa Vitória do Palmar, but not differing statistically from São Francisco de Paula. The São Joaquim 2 (SJ2) population has not presented statistical difference when cultivated at Caxias do Sul, Pelotas, and São Francisco de Paula, having a statistically lower biomass yield only at Santa Vitória do Palmar.

Relative to the populations average yield in all places, the André da Rocha, Capão Alto and Muitos Capões populations highlighted themselves as the most productive. Several authors reported that soil type and fertility, temperature differences and rainfall among cultivation regions have influence on the production, determining the adaptability to each cultivation place $[11,12]$.

The rainfall that occurred right after the planting, in December 2003 at Caxias do Sul and Erechim, with amounts of 287 and $310 \mathrm{~mm}$, respectively, and in the first weeks of January 2004 (Figure 1), were determinant for a better early development of the plants, enhancing the biomass production. At Santa Vitória do Palmar and Pelotas, besides the lower rainfall amounts, the rains were scarce right after the plantation, causing a higher plant mortality and a poorer development, even with irrigation after the plantation and in the periods in which water stress was critical. The percentage of dead plants in each place was: $25.34 \%$ in Erechim; 27.77\% in Caxias do Sul; 28.81\% in São Francisco de Paula; $56.00 \%$ in Pelotas e 51.38\% in Santa Vitória do Palmar.

Other factor that must be taken into account, but not being determinant for the low plant production in Pelotas and Santa Vitória do Palmar, were the higher temperatures in these places. The poejo occurs 
naturally in locations with medium to high altitude, which present milder temperatures [4], similar to the ones that occurred in the regions of Erechim, Caxias do Sul, and São Francisco de Paula.

Water stress being the main cause for the poor performance of the populations in Pelotas and Santa Vitória do Palmar, it was only possible carry out comparisons relative to the edaphological aspects in the three locations where the climatic conditions were similar.

Among these three locations, the average production was higher at Erechim. Between Caxias do Sul and São Francisco de Paula, in most cases, the production was statistically the same, with exception of André da Rocha, Capão Alto and Muitos Capões populations, which presented superior production at Caxias do Sul (Table 5). However, considering the populations average, the higher productions followed, in general, the order: Erechim, Caxias do Sul, and São Francisco de Paula, whose values were statistically distinct.

In Erechim, with the base fertilization carried out in the experiment (500 kg/ha NPK 5:20:10), the soil fertility may have been more balanced than in the other two locations, since this soil presented high $\mathrm{K}$ and low $\mathrm{P}$ contents before the base fertilizing. The $\mathrm{Ca} / \mathrm{K}$ molar relation was also balanced in this soil (Table 4). This better adequacy of the soil fertility may has proportioned a better productive response from most of the poejo populations. Still, this place, compared to the others, presented a higher soil clay content (Table 4).

On the other hand, the high P content found in the Caxias do Sul soil $(28 \mathrm{mg} / \mathrm{L})$, associated to the base fertilizing carried out, identical in all places, which added approximately $50 \mathrm{mg} / \mathrm{L}$ of $\mathrm{P}$ to the soil, may has impaired the performance of most populations when compared to the performance at Erechim. Several authors that worked with medicinal plants reported a quadratic-function response of several species to phosphate fertilizing, showing productivity when the soil has high doses of this element [24-26].

The lowest average biomass production of the populations was observed at São Francisco de Paula. This municipality is located in a region that is the natural habitat of poejo and, theoretically should be an ideal place, considering soil and climate factors, to the production of this species. It is worth mentioning that the soil at São Francisco de Paula had the lowest $\mathrm{K}$ content among all places, being also the soil with the most unbalanced $\mathrm{Ca} / \mathrm{K}$ and $\mathrm{Mg} / \mathrm{K}$ molar relations due to the high $\mathrm{Ca}$ and $\mathrm{Mg}$ contents (Table 4).

The obtained results suggested that the state of the soil fertility at the locations of Caxias do Sul and São Francisco de Paula were not the most appropriate for a better performance of the poejo populations. The $\mathrm{P}$, $\mathrm{Ca}$, and $\mathrm{Mg}$ contents found in these two locations were far above the contents found in the soils were this populations were found naturally, which are acidic, with high Al contents, and with a low natural fertility [4].

Regarding essential oil content, great differences were observed among the populations and the chemotypes, agreeing with the results reported by Fracaro and coauthors [1]. Besides these differences, a great variation among the cultivation places was also observed (Table 6).

Table 6. Essential oil yield (\% v/m) of the nine poejo populations cultivated in five agroclimatic regions of Rio Grande do Sul.

\begin{tabular}{|c|c|c|c|c|c|c|c|}
\hline \multirow[b]{2}{*}{ POP } & \multirow[b]{2}{*}{ CT } & \multicolumn{5}{|c|}{ Place } & \multirow[b]{2}{*}{$\begin{array}{c}\text { Mean } \\
\text { (POP) }\end{array}$} \\
\hline & & Erechim & Caxias do Sul & $\begin{array}{l}\text { São F. de } \\
\text { Paula }\end{array}$ & Pelotas & Santa V. do Palmar & \\
\hline AR & citral & 1.74 & 1.54 & 1.35 & 1.38 & 1.08 & 1.41 \\
\hline SL & menthene & 1.15 & 1.08 & 1.23 & 1.04 & 1.07 & 1.11 \\
\hline BJ & ocimene & 0.24 & 0.18 & 0.24 & 0.24 & 0.32 & 0.24 \\
\hline LA & menthene & 0.32 & 0.29 & 0.37 & 0.31 & 0.26 & 0.31 \\
\hline CAM & ocimene & 0.24 & 0.09 & 0.13 & 0.12 & 0.08 & 0.13 \\
\hline $\mathrm{CA}$ & ocimene & 0.23 & 0.39 & 0.32 & 0.65 & 0.28 & 0.37 \\
\hline SJ1 & menthene & 0.84 & 0.72 & 0.91 & 0.82 & 0.46 & 0.75 \\
\hline MC & citral & 1.11 & 1.01 & 0.85 & 0.84 & 0.61 & 0.88 \\
\hline SJ2 & menthene & 1.11 & 0.79 & 0.81 & 0.68 & 0.45 & 0.76 \\
\hline \multicolumn{2}{|c|}{ Mean (place) } & 0.77 & 0.67 & 0.69 & 0.72 & 0.51 & 0.67 \\
\hline
\end{tabular}

AR - André da Rocha; SL - Santa Lúcia; BJ - Bom Jardim; LA - Lages; CAM - Cambará do Sul; CA - Capão Alto; SJ São Joaquim; MC - Muitos Capões; SJ2 - São Joaquim 2.

The populations that presented the highest average essential oil yields were André da Rocha (AR) and Santa Lúcia (SL), independently of the place of cultivation. On the other hand, at Santa Vitória do Palmar occurred the lowest essential oil yields, when compared to the other places.

Some populations kept the essential oil yield stable in all places, as, for example, the Lages (LA) and Santa Lúcia (SL) populations. Other populations presented a decrease in the essential oil yield in the locations where it was also observed a reduction in the biomass production. The population André da Rocha 
presented a higher essential oil yield at Erechim $(1.74 \% \mathrm{v} / \mathrm{m})$ and the lowest yield was at Santa Vitória do Palmar $(1.08 \% \mathrm{v} / \mathrm{m})$, which were the best and worst places of biomass production, respectively (Table 5).

The Cambará do Sul (CAM) population presented its highest essential oil yield $(0.24 \% \mathrm{v} / \mathrm{m})$ at Erechim, which may be considered as an unfavorable environment for biomass production of this population, being quite superior to the other locations, which presented an average essential oil yield of $0.1 \% \mathrm{v} / \mathrm{m}$ (Table 5).

In this sense, Fuente and coauthors. [27], working with two coriander (Coriandrum sativum) varieties, one with the characteristic of producing large amounts of essential oil, and other with low essential oil production and high fruit production, cultivated in two environments, one considered favorable (high soil fertility) and other considered unfavorable (degraded soil), verified differences between the two varieties. The oil-producing variety increased the essential oil yield in the unfavorable environment. The authors attributed this to the fact that plants with biochemical routes that prioritize the production of secondary metabolites increase their production under unfavorable conditions. However, this fact was not observed in the André da Rocha population, which may be considered a population with high essential oil production.

The estimated essential oil yield (L/ha) is presented in Table 7. In Erechim, the poejo plants presented the highest average essential oil yields, followed by Caxias do Sul. The André da Rocha (AR) and Muitos Capões (MC) populations cultivated at Erechim presented the highest essential oil yields, producing 13.5 and 13.0 L/ha, respectively. Pauletti and coauthors. [28], cultivating nine poejo populations at Caxias do Sul and Campestre da Serra, South Brazil, in 2002 and 2003, also noted that these populations were the most productive in terms of essential oil yield.

Table 7. Estimated essential oil yield ( $\mathrm{L} / \mathrm{ha}$ ) of the nine poejo (C. galioides) populations, cultivated in five regions of Rio Grande do Sul.

\begin{tabular}{|c|c|c|c|c|c|c|c|}
\hline \multirow[b]{2}{*}{ POP } & \multirow[b]{2}{*}{ CT } & \multicolumn{5}{|c|}{ Place } & \multirow{2}{*}{$\begin{array}{l}\text { Mean } \\
(\mathrm{POP})\end{array}$} \\
\hline & & Erechim & Caxias do Sul & $\begin{array}{l}\text { São F. de } \\
\text { Paula }\end{array}$ & Pelotas & $\begin{array}{l}\text { Santa V. do } \\
\text { Palmar }\end{array}$ & \\
\hline AR & citral & 13.59 a A & $8.01 \mathrm{a} \mathrm{B}$ & 3.45 a C & 2.06 a D & 1.33 a D & $5.69 \mathrm{a}$ \\
\hline SL & menthene & $6.29 \mathrm{c} \mathrm{A}$ & 3.18 c B & $2.85 \mathrm{ab} B$ & $1.03 a b C$ & $1.20 \mathrm{a} \mathrm{C}$ & $2.91 \mathrm{c}$ \\
\hline BJ & ocimene & 0.78 ef $A$ & 0.31 e $A$ & $0.43 \mathrm{c} \mathrm{A}$ & $0.17 a b C$ & 0.14 a A & $0.36 \mathrm{~g}$ \\
\hline LA & menthene & 1.59 ef $A$ & 0.57 de $A B$ & $0.68 \mathrm{c} \mathrm{AB}$ & $0.34 \mathrm{~b} A B$ & 0.16 a B & $0.67 \mathrm{fg}$ \\
\hline CAM & ocimene & $0.36 \mathrm{f} \mathrm{A}$ & 0.30 e $A$ & 0.33 c A & $0.11 \mathrm{~b} \mathrm{~A}$ & 0.07 a $A$ & $0.23 \mathrm{~g}$ \\
\hline $\mathrm{CA}$ & ocimene & 2.25 e A & $2.00 \mathrm{~cd} \mathrm{AB}$ & $0.93 \mathrm{bc} B C$ & $1.03 \mathrm{ab} A B$ & 0.21 a C & 1.28 ef \\
\hline SJ & menthene & $4.40 \mathrm{~d} \mathrm{~A}$ & 1.08 de B & 1.62 bc B & $1.06 \mathrm{ab} B$ & 0.34 a B & $1.73 \mathrm{de}$ \\
\hline$M C$ & citral & $10.59 \mathrm{~b} \mathrm{~A}$ & 5.84 b B & $1.71 \mathrm{bc} C$ & $1.16 a b C$ & 0.86 a C & $4.03 \mathrm{~b}$ \\
\hline SJ2 & menthene & $6.07 \mathrm{c} \mathrm{A}$ & $1.56 \mathrm{~d} \mathrm{BC}$ & $1.78 \mathrm{bc} \mathrm{B}$ & $0.70 \mathrm{ab} B C$ & 0.28 a C & $2.08 \mathrm{~d}$ \\
\hline \multicolumn{2}{|c|}{ Mean (place) } & $5.11 \mathrm{~A}$ & $2.54 \mathrm{~B}$ & $1.53 \mathrm{C}$ & $0.85 \mathrm{D}$ & $0.51 \mathrm{D}$ & 2.11 \\
\hline
\end{tabular}

Means followed by the same letter, uppercase in row and lowercase in column, do not differ between themselves by Tukey's range test at 5\%. AR - André da Rocha; SL - Santa Lúcia; BJ - Bom Jardim; LA - Lages; CAM - Cambará do Sul; CA - Capão Alto; SJ - São Joaquim; MC - Muitos Capões; SJ2 - São Joaquim 2.

\section{STABILITY AND ADAPTABILITY OF THE POEJO POPULATIONS}

Tables 8 and 9 present the estimates for the stability and adaptability parameters for biomass and essential oil yields of the nine poejo populations. According to Silva [29], in collections of genotypes generally exist several adaptability patterns to the environment that distinguish themselves by different behaviors and response sensibilities to the environmental variations. A theoretically ideal genotype is considered the one that presents a high average response, and a low sensibility response to unfavorable conditions, and a high response in favorable conditions. For Eberhart and Russel [17], the ideal genotype is the one that presents a high average production, wide adaptability $(\beta=1)$ and high stability ( $\delta$ not significant).

Regarding biomass production, the populations André da Rocha (AR), Capão Alto (CA), and Muitos Capões (MC) presented the highest means (Table 10). However, these populations presented specific adaptability to favorable environments $(\beta>1)$, and among them, only the André da Rocha (Figure 3A) and Capão Alto populations presented high stability ( $\delta$ not significant). 
Table 8. Stability and adaptability parameters for the biomass production $(\mathrm{kg} / \mathrm{ha})$, according to the method proposed by Eberhart and Russel (17), for the poejo populations cultivated in five agroclimatic regions of Rio Grande do Sul, South Brazil.

\begin{tabular}{ccccc}
\hline Population & Mean $(\mathrm{m})$ & $\beta$ & $\delta$ & $\mathrm{R}^{2}$ \\
\hline AR & $366 \mathrm{a}$ & $1.36^{* *}$ & $1459.4^{\text {ns }}$ & 0.9739 \\
SL & $257 \mathrm{~b}$ & $0.88^{\text {ns }}$ & $-821.2^{\text {ns }}$ & 0.9898 \\
BJ & $159 \mathrm{c}$ & $0.52^{* *}$ & $-319.2^{\text {ns }}$ & 0.9420 \\
LA & $211 \mathrm{bc}$ & $0.81^{*}$ & $488.8^{\text {ns }}$ & 0.9543 \\
CAM & $184 \mathrm{bc}$ & $0.14^{* *}$ & $12427.1^{* *}$ & 0.0810 \\
CA & $403 \mathrm{a}$ & $1.77^{* *}$ & $-715.2^{\text {ns }}$ & 0.9968 \\
SJ & $214 \mathrm{bc}$ & $0.85^{\text {ns }}$ & $4659.7^{* *}$ & 0.8703 \\
MC & $402 \mathrm{a}$ & $1.72^{* *}$ & $6271.2^{* *}$ & 0.9560 \\
SJ2 & $226 \mathrm{bc}$ & $0.91^{\text {ns }}$ & $1791.9^{\text {ns }}$ & 0.9370 \\
\hline Overall mean & 269 & - & - & -
\end{tabular}

Significant at $1 \%\left({ }^{* *}\right)$ and significant at $5 \%\left(^{*}\right)$ probability by the t test $(\beta)$ and $F$ test $(\delta) ;{ }^{\text {ns }}-$ not significant. Means in column followed by the same letter do not present statistical difference by Tukey's range test at $5 \%$ probability. AR André da Rocha; SL - Santa Lúcia; BJ - Bom Jardim; LA - Lages; CAM - Cambará do Sul; CA - Capão Alto; SJ - São Joaquim; MC - Muitos Capões; SJ2 - São Joaquim 2.

The Santa Lúcia (Figure 3B) and São Joaquim 2 populations were the ones that presented wide adaptability and high stability for biomass production; however, their average productions were low, being below the overall mean of the populations.

Table 9. Stability and adaptability parameters according to Eberhart e Russel (1966) for the essential oil yield (L/ha) in the poejo populations cultivated in five agroclimatic regions of Rio Grande do Sul, South Brazil.

\begin{tabular}{ccccc}
\hline Population & Mean $(\mathrm{m})$ & $\beta$ & $\delta$ & $\mathrm{R}^{2}$ \\
\hline AR & $5.69 \mathrm{a}$ & $2.75^{* *}$ & $0.50^{* *}$ & 0.9822 \\
SL & $2.91 \mathrm{c}$ & $1.12^{\text {ns }}$ & $0.09^{\text {ns }}$ & 0.9653 \\
BJ & $0.36 \mathrm{~g}$ & $0.13^{*}$ & $-0.10^{\text {ns }}$ & 0.8708 \\
LA & $0.67 \mathrm{~g}$ & $0.28^{*}$ & $-0.08^{\text {ns }}$ & 0.9249 \\
CAM & $0.23 \mathrm{ef}$ & $0.05^{*}$ & $-0.10^{\text {ns }}$ & 0.6058 \\
CA & $1.28 \mathrm{de}$ & $0.39^{*}$ & $0.09^{\text {ns }}$ & 0.7789 \\
SJ & $1.70 \mathrm{ef}$ & $0.79^{*}$ & $0.32^{*}$ & 0.8684 \\
MC & $4.03 \mathrm{~b}$ & $2.23^{* *}$ & $0.54^{* *}$ & 0.9717 \\
SJ2 & $2.08 \mathrm{~d}$ & $1.21^{*}$ & $0.35^{* *}$ & 0.9341 \\
\hline
\end{tabular}

Overall mean 2.10

Significant at $1 \%\left({ }^{* *}\right)$ and significant at $5 \%\left(^{*}\right)$ probability by the $t$ test $(\beta)$ and $F$ test $(\delta) ;$ ns - not significant. Means in column followed by the same letter do not present statistical difference by Tukey's range test at $5 \%$ probability. AR André da Rocha; SL - Santa Lúcia; BJ - Bom Jardim; LA - Lages; CAM - Cambará do Sul; CA - Capão Alto; SJ - São Joaquim; MC - Muitos Capões; SJ2 - São Joaquim 2.

For essential oil production, the highest means were of the André da Rocha (Figure 4A) and Muitos Capões populations; however, the response of these populations regarding stability and adaptability parameters were not favorable. The Santa Lúcia population was the only one that presented wide adaptability and high stability for both biomass production and essential oil yield (Figures 3B and 4B).
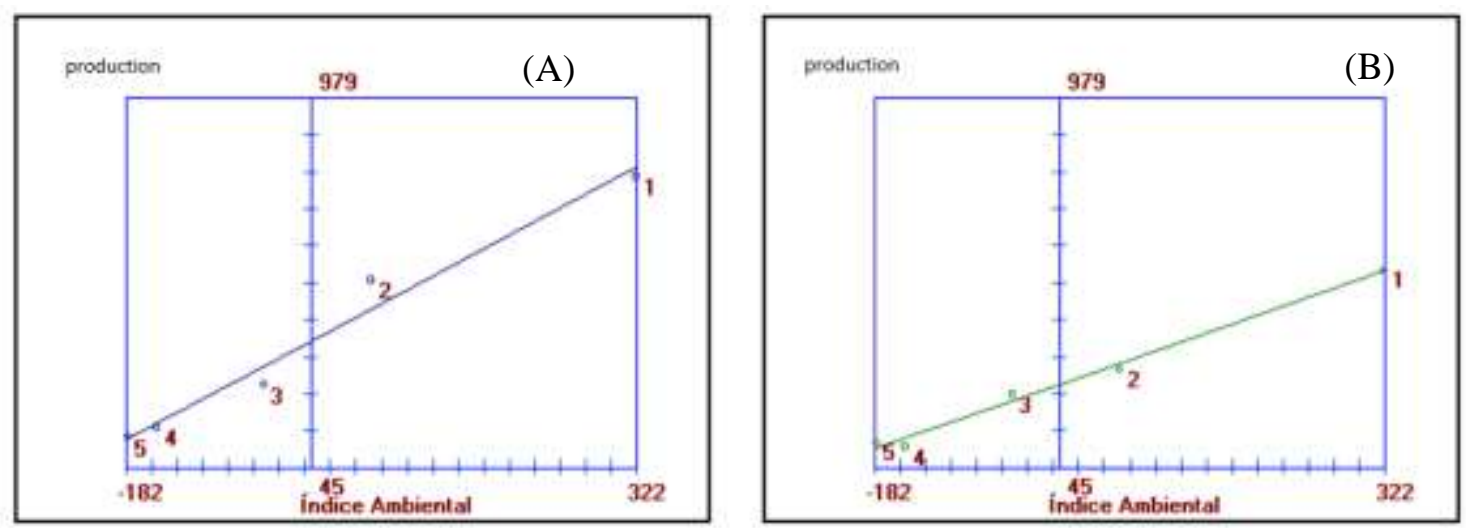

Figure 3. Graphical representation of adaptability and stability for biomass production. A - André da Rocha population presenting specific adaptability to favorable environments. B - Santa Lúcia population presenting wide adaptability and high stability. 

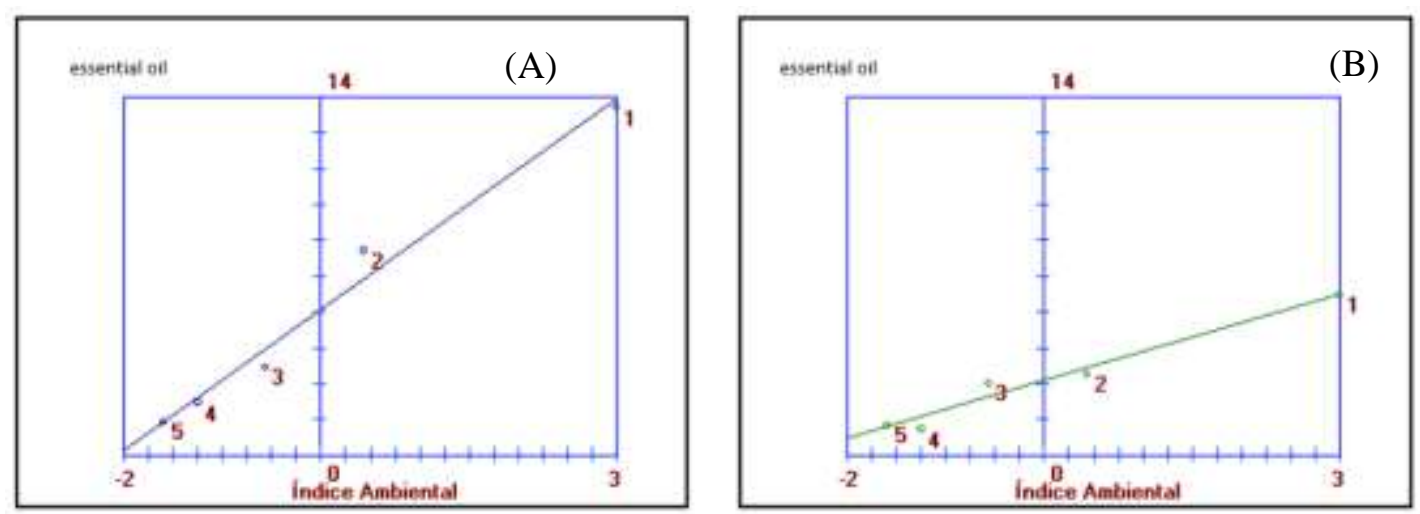

Figure 4. Graphical representation of adaptability and stability for essential oil production. A - André da Rocha population presenting specific adaptability to favorable environments. B - Santa Lúcia population presenting wide adaptability and high stability.

\section{Poejo production in the second year of cultivation}

In Erechim, where the majority of the populations have had a good performance, a productivity evaluation was carried out in the second year of cultivation, aiming to evaluate the behavior of the populations after the first harvesting.

The accumulated rainfall in Erechim in the period between the first and second harvests (May 2004 to April 2005) was $1277 \mathrm{~mm}$. Figure 5 presents the monthly rainfall, where it was observed the low rainfall amount in the months of December 2004 and February 2005. In this agricultural year, the rainfall was quite below the annual average rainfall $(1590 \mathrm{~mm})$, and the average rainfall in the period of December to March $(560 \mathrm{~mm}$ ) in the region [20]. The rainfall in the summer period was $348 \mathrm{~mm}$, being almost half of the rainfall in the same period of $2003 / 2004$, despite being a year of El Niño occurrence, which is characterized by causing rainy summers [21].

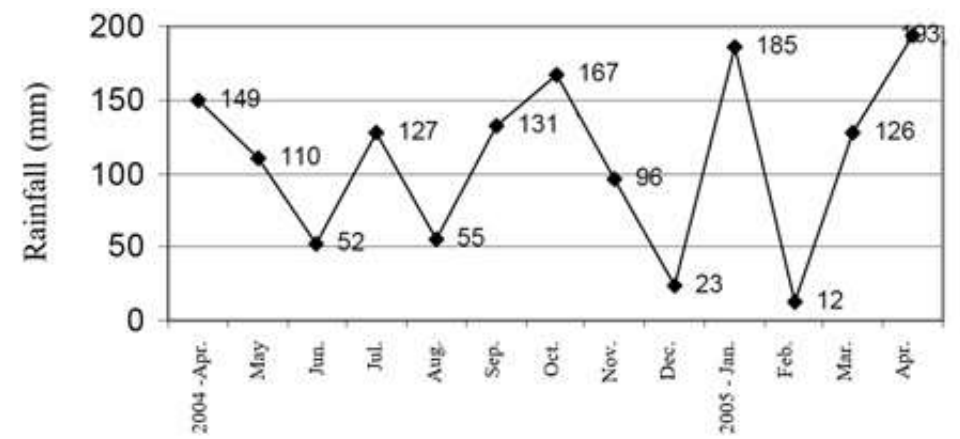

Figure 5. Monthly rainfall occurred in the municipality of Erechim in the period of May 2004 to April 2005.

Table 10 presents the estimates for biomass production and essential oil yield per hectare in the first and second years of cultivation; it was observed that some populations presented productions that were quite superior in the second year.

Table 10. Biomass production (kg/ha) and essential oil production (L/ha) in the nine poejo (C. galioides) populations, in two years of cultivation, in the city of Erechim, RS.

\begin{tabular}{cccccc}
\hline \multirow{2}{*}{ POP } & \multirow{2}{*}{ CT } & \multicolumn{2}{c}{2004} & DM & EO $^{*}$ \\
\cline { 3 - 6 } & & DM & EO & 2005 \\
AR & citral & $778.54 \mathrm{a} \mathrm{B}$ & 13.59 & $2389.88 \mathrm{a} \mathrm{A}$ & 41.56 \\
SL & menthene & $545.15 \mathrm{ab} \mathrm{B}$ & 6.29 & $1398.71 \mathrm{bc} \mathrm{A}$ & 16.08 \\
BJ & ocimene & $324.69 \mathrm{ab} \mathrm{A}$ & 0.78 & $456.16 \mathrm{de} \mathrm{A}$ & 1.09 \\
LA & menthene & $496.67 \mathrm{ab} \mathrm{A}$ & 1.59 & $662.00 \mathrm{de} \mathrm{A}$ & 2.11 \\
CAM & ocimene & $148.07 \mathrm{~b} \mathrm{~A}$ & 0.36 & $91.96 \mathrm{e} \mathrm{A}$ & 0.22 \\
CA & ocimene & $975.41 \mathrm{a} \mathrm{B}$ & 2.25 & $1506.94 \mathrm{~b} \mathrm{~A}$ & 3.46 \\
SJ & menthene & $537.17 \mathrm{ab} \mathrm{A}$ & 4.40 & $726.74 \mathrm{cde} \mathrm{A}$ & 6.10 \\
MC & citral & $951.51 \mathrm{a} \mathrm{A}$ & 10.59 & $911.67 \mathrm{bcd} \mathrm{A}$ & 10.11 \\
SJ2 & menthene & $545.80 \mathrm{ab} \mathrm{A}$ & 6.07 & $528.54 \mathrm{de} \mathrm{A}$ & 5.86 \\
\hline
\end{tabular}

DM - dry matter; EO - essential oil. Means followed by the same letter, uppercase in row and lowercase in column, do not differ between themselves by Tukey's range test at 5\%.; ${ }^{*}$ - estimated using essential oil yield of 2004. AR - André 
da Rocha; SL - Santa Lúcia; BJ - Bom Jardim; LA - Lages; CAM - Cambará do Sul; CA - Capão Alto; SJ - São Joaquim; MC - Muitos Capões; SJ2 - São Joaquim 2.

The three populations that most highlighted themselves in the second year regarding dry biomass production were André da Rocha (2,388 kg/ha), Capão Alto $(1,506 \mathrm{~kg} / \mathrm{ha})$, and Santa Lúcia $(1,398 \mathrm{~kg} / \mathrm{ha})$, being the production $67 \%, 61 \%$, and $35 \%$ significantly superior in relation to the first year, respectively. The other populations have not presented statistical differences between the two years; some of them kept the productivity level. The population Cambará do Sul was the one that presented the worst biomass production in the first year, diminishing even more its production in the second year, but without statistical difference.

The populations Capão Alto and Muitos Capões, which presented the highest productivities in the first year of cultivation, presented different responses in the second year. The Capão Alto population increased significantly its production; the Muitos Capões population remained stable, indicating that very probably this population already reaches its maximum productivity in the first year of cultivation.

Alquezar [11], working with different semi-perennial aromatic species from the Lamiaceae family, observed that some species start their production in the first year, while others presented a more significant production from the second year of cultivation.

The higher production of some populations in the second year, when the rainfall was lower than in the first year, may be explained because the plant was already established, with a more vigorous root system, proportionating a higher resistance to water stress.

\section{Chemical composition of the essential oil}

The nine poejo populations used in the present study were classified, according to Echeverrigaray and coauthors. [4], in three chemotypes (CT). The André da Rocha and Muitos Capões populations were of the CT-citral; the Cambará do Sul, Capão Alto, and Bom Jardim da Serra populations were of the CT-ocimene; and the Santa Lúcia, São Joaquim, São Joaquim 2, and Lages populations were of the CT-menthene [2,28].

The average content of the chemical compounds of the nine populations cultivated in the five regions of Rio Grande do Sul can be observed in Table 11. Twenty-six different chemical compounds were identified, including monoterpenes, sesquiterpenes and oxygenated compounds. The obtained results are in accordance to the ones of Echeverrigaray and coauthors [28], who worked with the same poejo populations.

According to Bordignon [30], the essential oil of many species of the Cunila genus ( $C$. incisa, $C$. angustifolia, C. menthoides, C. platyphylla, C. fasciculata, and C. microcephala) are characterized by the predominance of monoterpenes, in general presenting a major compound. By the essential oil analysis, it could be observed that, in most populations, the chemical composition remained stable, with changes in the contents of some minor compounds, depending on the population and place of cultivation.

In the populations of the CT-ocimene and in one population of the CT-citral (Muitos Capões), it was observed smaller amounts of the monoterpenes trans- $\beta$-ocimene and citral (neral and geranial), which characterize this chemotypes. Fracaro and coauthors [1] and Echeverrigaray and coauthors [4] reported larger amounts of these compounds, with a citral content of approximately $70 \% \mathrm{~m} / \mathrm{m}$ in the Muitos Capões population and trans- $\beta$-ocimene content ranging between 10 and $46 \% \mathrm{~m} / \mathrm{m}$ in the populations of the ocimene chemotype.

The Muitos Capões population presented an average citral content of $4.8 \% \mathrm{~m} / \mathrm{m}$ (Table 11), being observed a large variation with the environment. The highest content was observed at Erechim $(8.1 \% \mathrm{~m} / \mathrm{m})$ and the lowest at Santa Vitória do Palmar $(1.2 \% \mathrm{~m} / \mathrm{m})$. In the populations with the ocimene chemotype, the contents were extremely low in all places, ranging from trace amounts up to $2.5 \% \mathrm{~m} / \mathrm{m}$. In the Bom Jardim da Serra population, the compound trans- $\beta$-ocimene was not detected (Table 11).

In the populations which has occurred a reduction in the monoterpene amounts in the essential oil, it was observed larger amounts of sesquiterpenes, as caryophyllene oxide, spathulenol, $\alpha$-cadinol and ledene (Table 11). These compounds were not identified, or the amounts were insignificant, in the studies of Fracaro and coauthors [1] and Echeverrigaray and coauthors [4].

According to Harbone [31], the sesquiterpenes are the main class of secondary metabolites that have several ecologic defensive functions in the plants, the amounts of these compounds are increased due to environmental stress. It was observed an increase in the sesquiterpene amounts and decrease in the monoterpene amounts in the essential oils of the Muitos Capões population and in the three populations of the ocimene chemotype, in all places. This behavior may be attributed to environmental stress, since water stress occurred in all places. 
Differently from the pattern observed in this poejo populations, Simon and coauthors [32] verified that water stress altered the chemical composition of basil essential oil (Ocimum basilicum - Lamiaceae), showing a reduction in sesquiterpenes amounts. Such discrepancies may be attributed to a distinct response to the environment according to each population or species.

On the other hand, some populations kept their chemical profile practically unchanged, such as André da Rocha (CT-citral) and all populations with the menthene chemotype. The André da Rocha population kept citral (neral and geranial) content practically constant, in all places, with average neral and geranial contents of $31.6 \pm 0.9 \% \mathrm{~m} / \mathrm{m}$ and $46.0 \pm 0.6 \% \mathrm{~m} / \mathrm{m}$, respectively (Table 11). The Lages population (CT-menthene) kept a similar chemical composition in all places, presenting high borneol amounts $(29.4 \pm 1.6 \% \mathrm{~m} / \mathrm{m}$ - Table 11$)$, which, according to Echeverrigaray and coauthors [4], is a characteristic of this population. Among the menthene chemotype populations, Lages highlighted itself because it presented a high camphene content $(10.0 \pm 2.0 \% \mathrm{~m} / \mathrm{m})$, with small variations among the places.

Loziene and Venskutonis [8], who worked with five chemotypes of lemon thyme (Thymus pulegioides Lamiaceae), based in the stability of the essential oil composition against changes in environmental conditions, observed that some chemotypes are strongly affected by the environmental conditions, while others remain with a relatively stable chemical composition. The authors attributed this fact to an interaction between the genetic and environmental factors. Limonene was also found in almost all populations, with distinct contents, being present in higher amounts in the populations with the menthene chemotype. Particularly, in the populations São Joaquim and São Joaquim 2 it was observed a sharp reduction of limonene amounts when these populations were cultivated in Pelotas and Santa Vitória do Palmar, places where the plants suffered greater water stress.

Shahi and coauthors [9], cultivating Mentha x piperita (Lamiaceae) in different regions of India, observed a reduction of limonene contents at lower altitudes and higher photoperiods, considering that the synthesis of this compound may be strongly influenced by the environmental conditions. Pelotas and Santa Vitória do Palmar, besides the low altitude, presented higher photoperiods when compared to Caxias do Sul, São Francisco de Paula, and Erechim.

In a study carried out by Pauletti and coauthors [33], on which poejo plants underwent changes in some nutrient levels by liming, it was observed changes in the amounts of some essential oil components, with reduction of citral and limonene contents in the André da Rocha and Santa Lúcia populations, respectively. The chemical composition of the essential oil of the Bom Jardim da Serra population has not changed with liming. Nevertheless, stress by aluminum $\left(\mathrm{Al}^{3+}\right)$ [34], has not altered the essential oil composition of the same populations. These facts demonstrate that modifications in the chemical composition of poejo essential oil depend on the kind of stress and the population (chemotype) cultivated, being a result of an interaction between genetic and environmental factors, as observed by Loziene and Venskutonis [8]. 
Table 11. Essential oil composition (mean \pm standard deviation) in mass percentage of the nine poejo (C. galioides) populations cultivated in five agroclimatic regions of Rio Grande do Sul.

\begin{tabular}{|c|c|c|c|c|c|c|c|c|c|c|c|}
\hline Component & LRI Calc. & LRI Ref [19] & $\mathrm{AR}$ & MC & BJ & $\mathrm{CA}$ & CAM & LA & SL & SJ & SJ2 \\
\hline a-pinene & 930 & 932 & $0.1 \pm 0.02$ & $1.1 \pm 0.73$ & - & $1.5 \pm 0.66$ & $1.6 \pm 0.43$ & $4.8 \pm 1.00$ & $0.6 \pm 0.22$ & $0.3 \pm 0.15$ & $2.3 \pm 0.08$ \\
\hline camphene & 956 & 955 & - & - & - & $1.4 \pm 0.01$ & $2.8 \pm 2.16$ & $10.3 \pm 1.99$ & - & - & - \\
\hline sabinene & 962 & 969 & $0.2 \pm 0.02$ & $1.2 \pm 0.51$ & - & $2.6 \pm 1.88$ & $1.1 \pm 0.33$ & $1.0 \pm 0.19$ & $0.3 \pm 0.11$ & $0.6 \pm 0.06$ & $0.4 \pm 0.13$ \\
\hline$\beta$-pinene & 971 & 970 & $0.4 \pm 0.05$ & $1.0 \pm 0.50$ & - & $1.5 \pm 0.01$ & $0.5 \pm 0.14$ & $1.9 \pm 0.38$ & $0.5 \pm 0.16$ & $0.7 \pm 0.06$ & $0.5 \pm 0.12$ \\
\hline octen-3-ol & 973 & 974 & $0.2 \pm 0.07$ & $0.3 \pm 0.15$ & $0.5 \pm 0.37$ & $1.9 \pm 0.76$ & $1.6 \pm 0.90$ & $0.1 \pm 0.01$ & $0.4 \pm 0.28$ & $0.5 \pm 0.20$ & - \\
\hline myrcene & 990 & 988 & $0.1 \pm 0.05$ & $0.6 \pm 0.37$ & - & $0.3 \pm 0.08$ & $0.8 \pm 0.38$ & $0.4 \pm 0.11$ & $0.5 \pm 0.18$ & $0.5 \pm 0.06$ & $0.4 \pm 0.16$ \\
\hline $\begin{array}{c}\text { trans-2,8- } \\
\text { menthadiene }\end{array}$ & 1005 & 1002 & - & - & - & - & $2.4 \pm 2.11$ & $1.5 \pm 0.27$ & $1.3 \pm 0.41$ & $1.9 \pm 0.75$ & $2.7 \pm 1.21$ \\
\hline$\rho$-cymene & 1020 & 1022 & - & - & - & $0.6 \pm 0.12$ & $0.6 \pm 0.20$ & $0.3 \pm 0.08$ & $0.1 \pm 0.02$ & - & - \\
\hline limonene & 1024 & 1024 & $0.2 \pm 0.06$ & $3.6 \pm 1.50$ & - & $1.5 \pm 0.97$ & $0.6 \pm 0.49$ & $5.5 \pm 0.63$ & $14.0 \pm 4.44$ & $13.7 \pm 8.98$ & $9.9 \pm 8.18$ \\
\hline 1,8 -cineole & 1030 & 1026 & $0.2 \pm 0.02$ & $5.3 \pm 3.24$ & - & - & - & - & - & - & - \\
\hline trans- $\beta$-ocimene & 1042 & 1044 & $0.1 \pm 0.03$ & $1.7 \pm 1.01$ & - & $0.5 \pm 0.57$ & $1.6 \pm 0.90$ & $0.4 \pm 0.12$ & $0.6 \pm 0.20$ & $0.1 \pm 0.06$ & - \\
\hline $\mathrm{v}$-terpinene & 1055 & 1054 & $0.3 \pm 0.11$ & $1.7 \pm 0.70$ & - & $0.6 \pm 0.14$ & $4.4 \pm 5.54$ & $0.1 \pm 0.01$ & $0.8 \pm 0.38$ & $0.6 \pm 0.19$ & - \\
\hline linalool & 1099 & 1095 & $1.9 \pm 0.27$ & $2.0 \pm 0.80$ & $0.6 \pm 0.31$ & $2.0 \pm 0.68$ & $1.7 \pm 0.83$ & $2.7 \pm 0.53$ & $1.6 \pm 0.46$ & $1.3 \pm 0.42$ & $1.2 \pm 0.37$ \\
\hline $\begin{array}{c}1,3,8-p- \\
\text { menthatriene }\end{array}$ & 1112 & 1108 & - & - & - & - & $0.9 \pm 1.05$ & $4.0 \pm 0.23$ & $18.1 \pm 2.76$ & $16.8 \pm 3.44$ & $17.4 \pm 2.63$ \\
\hline $\begin{array}{c}1,5,8-p- \\
\text { menthatriene }\end{array}$ & 1111 & 1110 & - & - & - & - & $2.8 \pm 0.62$ & $9.4 \pm 1.41$ & $26.3 \pm 6.37$ & $16.9 \pm 2.28$ & $19.7 \pm 2.71$ \\
\hline borneol & 1165 & 1165 & $1.0 \pm 0.15$ & $4.0 \pm 0.66$ & $11.9 \pm 7.21$ & $11.9 \pm 7.21$ & - & $29.4 \pm 1.58$ & $15.8 \pm 2.47$ & $15.1 \pm 2.99$ & $15.2 \pm 2.22$ \\
\hline neral & 1230 & 1235 & $31.6 \pm 0.94$ & $1.8 \pm 1.15$ & - & - & - & - & - & - & - \\
\hline geranial & 1266 & 1264 & $46.0 \pm 0.64$ & $3.0 \pm 1.74$ & $0.3 \pm 0.14$ & $0.3 \pm 0.14$ & - & $0.8 \pm 0.37$ & $3.1 \pm 1.36$ & $4.6 \pm 1.12$ & $6.6 \pm 1.79$ \\
\hline geranyl acetate & 1376 & 1379 & $4.8 \pm 1.21$ & $0.7 \pm 0.25$ & - & - & - & - & - & - & - \\
\hline aromadendrene & 1438 & 1439 & - & - & - & - & - & $1.1 \pm 0.29$ & - & $1.7 \pm 0.62$ & $1.8 \pm 0.37$ \\
\hline ledene & 1499 & 1496 & - & - & $67.8 \pm 3.02$ & - & - & - & - & - & - \\
\hline spathulenol & 1578 & 1577 & $0.2 \pm 0.06$ & $16.6 \pm 4.77$ & $6.0 \pm 1.36$ & $3.1 \pm 1.00$ & $1.5 \pm 0.55$ & $0.2 \pm 0.08$ & $0.8 \pm 0.39$ & $1.3 \pm 0.79$ & $0.9 \pm 0.32$ \\
\hline caryophyllene oxide & 1580 & 1582 & $3.2 \pm 0.56$ & $17.2 \pm 4.22$ & $12.6 \pm 2.86$ & $36.4 \pm 2.44$ & $8.7 \pm 5.68$ & $1.1 \pm 0.77$ & $0.7 \pm 0.57$ & $2.8 \pm 2.33$ & $1.6 \pm 1.53$ \\
\hline viridiflorol & 1592 & 1592 & - & - & - & $10.7 \pm 1.45$ & $2.9 \pm 0.93$ & $1.7 \pm 0.60$ & - & $2.6 \pm 0.94$ & $2.4 \pm 0.48$ \\
\hline a-cadinol & 1655 & 1652 & - & - & - & $2.9 \pm 0.44$ & $29.1 \pm 6.31$ & - & - & - & - \\
\hline not identified & - & - & 9.9 & 40.2 & 11.4 & 24.3 & 31.1 & 23.4 & 14.4 & 18.8 & 19.1 \\
\hline monoterpenes & - & - & 86.7 & 25.9 & 2.0 & 23.7 & 16.4 & 72.5 & 84.1 & 72.8 & 74.2 \\
\hline sesquiterpenes & - & - & 3.4 & 33.9 & 86.6 & 52.0 & 52.5 & 4.1 & 1.5 & 8.4 & 6.7 \\
\hline total & - & - & 90.1 & 59.8 & 88.6 & 75.7 & 68.9 & 76.6 & 85.6 & 81.2 & 80.9 \\
\hline
\end{tabular}

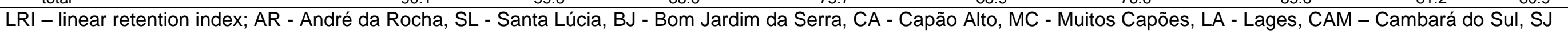

- São Joaquim, SJ2 - São Joaquim 2. 


\section{CONCLUSION}

It was observed that qualitative differences occurred among the poejo populations according to the place and year of cultivation. The better place for production for most poejo populations was Erechim; however, the Cambará do Sul population did not perform satisfactorily in this place, indicating that an interaction between genotype and environment took place. The populations presented distinct essential oil yields, according to the place (environment) of cultivation. Some populations kept stable yields, others diminished the essential oil yield in environments considered unfavorable for biomass production, while others had increased the yields in these conditions. The Santa Lúcia population presented wide adaptability and a high stability for biomass and essential oil production in the different environments, but its average production was smaller than other populations at other locations. The André da Rocha population presented the highest average production of essential oil, being favored in favorable environments. It was observed, in the essential oil of some populations, in all places, higher amounts of sesquiterpenes in relation to the monoterpenes amounts, being this attributed to environmental stress, mainly water stress.

Funding: This research received no external funding.

Conflicts of Interest: The authors declare no conflict of interest.

\section{REFERENCES}

1. Fracaro F, Serafini LA, Santos ACA, Paroul N, Echeverrigaray S, Wasum R. Analysis of the Essential Oil Composition of Cunila galioides Benth. J. Essent. Oil Res. 2002; 14:336-8.

2. Fracaro F, Zacaria J, Echeverrigaray S. RAPD based genetic relationships between populations of three chemotypes of Cunila galioides Benth. Biochem. Syst. Ecol. 2005; 33:409-17.

3. Agostini F, Santos ACA, Rossato M, Pansera MR, Santos PL, Serafini LA, Molon R, Moyna P. Essential oil yield and composition of Lamiaceae species growing in Southern Brazil. Braz. Arch. Biol. Technol. 2009; 52:473-8.

4. Echeverrigaray S, Fracaro F, Santos ACA, Paroul N, Wasum R, Serafini LA. Essential oil yield and composition of South Brazilian population of Cunila galioides and its relation with the geographic distribution. Biochem. Syst. Ecol. 2003; 31:467-75.

5. Hay RKM, Waterman PG. Volatile oil crops: their biology, biochemistry, and production. Technical LS\&, Harlow, 1993.

6. Cunha JA, Scheeren CA, Salbego J, Gressler LT, Madaloz LM, Bandeira-Júnior G, Bianchini AE, Pinheiro CG, Bordignon SAL, Heinzmann BM, Baldisserotto B. Essential oils of Cunila galioides and Origanum majorana as anestesics for Rhamdia quelen: efficacy and effects on ventilation and ionoregulation. Neotrop. Ichthyol. 2017; 15:1-8.

7. Pauletti, GF. Influência ambiental e de parâmetros agronômicos na produção de poejo (Cunila galioides Benth.) [Ph.D. thesis]. Porto Alegre (RS): Federal University of Rio Grande do Sul, 2005.

8. Loziene K, Venskutonis PR. Influence of environmental and genetic factors on the stability of essential oil composition of Thymus pulegioides. Biochem Syst. Ecol. 2005; 33:517-25.

9. Shahi AK, Chandra S, Dutt P, Kaul BL, Tava A, Avato P. Essential oil composition of Mentha x piperita L. from different environments of North India. Flavour Fragr. J. 1999; 14:5-8.

10. Bandoni AL. Los recursos vegetales aromáticos en Latinoamérica: su aprovechamiento industrial para la producción de aromas y sabores. 2nd ed. Buenos Aires: Universidad Nacional de La Plata, 2002. 410 p.

11. Alquézar JB. Investigación y experimentación de plantas aromáticas y medicinales en Aragón: cultivo, transformación y analítica. Zaragoza: Gobierno de Aragón, 2003. 262 p.

12. World Health Organization (WHO). WHO guidelines on good agricultural and collection practices (GACP) for medicinal plants. Geneva: WHO, 2003. 80 p.

13. Justus B, Almeida VP, Gonçalves MM, Assunção DPSF, Borsato DM, Arana AFM, Maia BHLNS, Paula JFP, Budel JM, Farago PV. Chemical Composition and Biological Activities of the Essential Oil and Anatomical Markers of Lavandula Dentata L. Cultivated in Brazil. Braz. Arch. Biol. Technol. 2018; 61:1-12.

14. Fracaro F, Echeverrigaray S. Micropropagation of Cunila galioides, a popular medicinal plant from South Brazil. Plant Cell Tissue Cult. 2001; 64:1-4.

15. Rheinheimer DS, Gatiboni LC, Kaminski J, Robaina AD, Anghinoni I, Flores, JPC, Horn D. Situação da fertilidade dos solos no Estado do Rio Grande do Sul. UFSM: Santa Maria, 2001. 41 p.

16. Tedesco MJ, Gianello C, Bissiani CA, Bonhem H, Volkweiss SJ. Análise de solo, plantas e outros materiais. 2nd ed. Porto Alegre: Departamento de Solos da UFRGS, 1995. 
17. Cruz CD, Regazzi AJ. Modelos biométricos aplicados ao melhoramento genético. Viçosa: Editora UFV, 1997. 390 p.

18. Cruz CD. Programa Genes - versão Windows: aplicativo computacional em genética e estatística. Viçosa: Editora UFV, 2001.

19. Adams RP. Identification of Essential Oil components by gas chromatography/mass spectrometry, 4th ed. Waco: Allured Publishing, 2017. 809 p.

20. Berlato MA, Cordeiro APA. Variabilidade climática e agricultura do Rio Grande do Sul. In: As estiagens e perdas na agricultura: fenômeno natural ou imprevidência? Porto, R.O.; Porto Alegre: Ideograf, 2005. p. 43-59.

21. Porto RO. As estiagens e perdas na agricultura: fenômeno natural ou imprevidência? Porto Alegre: Ideograf, 2005. p. 43-59.

22. Mello FAF, Sobrinho MOCB, Arzolla A, Silveira RI, Netto C, Kihel JC. Fertilidade do Solo. São Paulo: Nobel, 1983. $400 \mathrm{p}$.

23. Siqueira OJF, Scherer EE, Tassinari G, Anghinoni I, Patella JF, Tedesco MJ, Milan PA, Ernani PR, Wietholter S. Recomendações de adubação e calagem para os estados do Rio Grande do Sul e Santa Catarina, Passo Fundo: SCBS-NRS, 1989. $128 \mathrm{p}$.

24. Sousa MMM, Ledó FJS, Pimental FA. Efeito da adubação e do calcário na produção de matéria seca e de óleo essencial de pimenta-longa. Pesqui. Agropec. Bras. 2001; 36:405-9.

25. Freitas MSM, Martins MA, Vieira IJC. Produção e qualidade de óleos essenciais de Mentha arvensis em resposta à inoculação de fungos micorrízicos arbusculares. Pesqui. Agropec. Bras. 2004; 39:887-94.

26. Rodrigues CR, Faquin V, Trevisan D, Pinto JEBP, Bertolucci SKV, Rodrigues TM. Nutrição mineral, crescimento e teor de óleo essencial da meta em solução nutritiva sob diferentes concentrações de fósforo e épocas de colheita. Hortic. Bras. 2004; 22:573-8.

27. Fuente EB, Gil A, Lenardis AE, Pereira ML, Suárez SA, Ghersa CM, Grass MY. Response of winter crops differing in grain yield and essential oil production to some agronomic practices and environmental gradient in the Rolling Pampa, Argentina. Agric. Ecosyst. Environ. 2003; 99:159-69.

28. Pauletti GF, Barros IBI, Echeverrigaray S, Serafini LA, Rota LD, Santos ACA. Análise quantitativa da produção de óleos essenciais de Cunila galioides Benth. (poejo) cultivada no Rio Grande do Sul. Hortic. Bras. 2003; 21:408.

29. Silva JGC. Agrupamento de genótipos segundo a adaptabilidade do ambiente. Pesqui. Agropec. Bras. 1995; 30:1141-54.

30. Bordingnon SAL. Estudo botânico e químico de espécies de Cunila Royen ex L. (Lamiaceae) nativas do Sul do Brasil [Ph.D. thesis]. Porto Alegre: Federal University of Rio Grande do Sul, 1997.

31. Harbone JB. Plant secondary metabolism. In: Plant Ecology; Oxford: Science B, 1997. p. 717.

32. Simon JE, Reiss-Bubenhheim D, Joly RJ, Charles DJ. Water stress-induced alterations in Essential Oil content and composition of sweet basil. J. Essent. Oil Res. 1992; 4:71-5.

33. Mossi AJ, Pauletti GF, Rota LD, Echeverrigaray S, Barros IBI, Oliveira JV, Paroul N, Cansian RL. Effect of different liming levels on the biomass production and essential oil extraction yield of Cunila galioides Benth. Braz. J. Biol. 2012; 72:787-93.

34. Mossi AJ, Pauletti GF, Rota LD, Echeverrigaray S, Barros IBI, Oliveira JV, Paroul N, Cansian RL. Effect of aluminum concentration on growth and secondary metabolites production in three chemotypes of Cunila galioides Benth. medicinal plant. Braz. J. Biol. 2011; 71:1003-9.

(C) 2020 by the authors. Submitted for possible open access publication under the terms and conditions of the Creative Commons Attribution (CC BY NC) license (https://creativecommons.org/licenses/by-nc/4.0/). 